\title{
Selenium and vitamin $\mathrm{E}$ in relation to risk factors for coronary heart disease
}

\author{
NIA ELLIS, ${ }^{*}$ BARBARA LLOYD,${ }^{*}$ RS LLOYD,$\dagger$ BARBARA E CLAYTON* \\ From the University Department of Chemical Pathology and Human Metabolism, ${ }^{*}$ and the Professorial \\ Medical Unit, $\dagger$ Faculty of Medicine, University of Southampton, Southampton General Hospital, Tremona \\ Road, Southampton, SO9 $4 X Y$
}

SUMMARY Fasting blood samples taken from 116 apparently healthy men aged 30-50 years were assayed for selenium, glutathione peroxidase activity, vitamin E, cadmium, lead, glucose, lipids, and albumin. Blood pressure was measured in each subject, and details of height, weight, smoking habits, and alcohol consumption were recorded.

Multivariate analysis of the data showed that the decrease in blood and serum concentrations of selenium and the increase in whole blood cadmium concentrations in the cigarette smokers was independent of alcohol consumption. There was no correlation between blood selenium concentrations or glutathione peroxidase activities and the risk factors for cardiovascular disease. Neither alcohol consumption nor smoking had an effect on the vitamin $E$ concentrations. There was a strong association, however, between vitamin $\mathrm{E}$ and serum lipid concentrations, although the increase in triglyceride concentrations in the smokers was not matched by a comparable increase in vitamin $\mathrm{E}$. The possible role of selenium in the aetiology of heart disease remains unresolved

A number of studies have suggested that hyperlipidaemia, hypertension, obesity, diabetes, and cigarette smoking may be possible risk factors in the aetiology of coronary heart disease. ${ }^{1-3}$ Although risk factor intervention trials have not been conclusive, ${ }^{4}$ there seems to be general agreement on the relation between cigarette smoking and coronary heart disease, together with the improved prognosis that follows cessation of smoking. ${ }^{5}$

The trace elements lead and cadmium have also been implicated in heart disease. ${ }^{67}$ It has been suggested that the higher incidence of cardiovascular mortality in soft water areas may be due to the increased lead concentrations found in many soft waters. ${ }^{8}$ Shaper et $a l^{8}$ have shown a strong association between blood lead concentrations, alcohol consumption, and cigarette smoking. Blood cadmium concentrations are higher in cigarette smokers than in non-smokers, ${ }^{9}$ but the evidence linking blood cadmium to hypertension in man is equivocal. ${ }^{10} 11$ A pressor effect of cadmium in drink-

Accepted for publication 7 November 1983 ing water fed to rats has been reported. This effect was reversed by the addition to the drinking water of another trace element, selenium. ${ }^{12}$

Recently there has been growing interest in the role of selenium in relation to coronary heart disease. The effects of selenium deficiency in animals have been well documented. For example, rats and lambs fed selenium deficient diets developed abnormal electrocardiograms accompanied by blood pressure changes, ${ }^{1314}$ and young pigs fed a semi- $\frac{D}{O}$ synthetic diet deficient in selenium and vitamin $E \cong$ developed a cardiomyopathy, which was clearly $\tilde{N}$ shown by histological techniques. ${ }^{15}$

Epidemiological studies have shown an inverse 0 relation between selenium and mortality due to $\omega$ heart disease. ${ }^{16} \mathrm{~A}$ report from the People's Republic $\sigma$ of China suggests the importance of sodium selenite $\varrho$ in the prevention and treatment of Keshan's disease, a fatal cardiomyopathy affecting mainly children and pregnant women. ${ }^{17}$ Salonen et al ${ }^{18}$ showed a significant relation between the concentration of $\frac{\vec{D}}{D}$ selenium in serum and cardiovascular death and myocardial infarction, and Oster et al ${ }^{19}$ suggested $\stackrel{\mathbb{Q}}{\square}$ that a deficiency of selenium may be present in a 
number of patients with cardiomyopathy.

In a recent study we found that the concentration of selenium in whole blood and plasma was significantly lower in male cigarette smokers over 30 years of age compared with non-smoking controls of a similar age..$^{20}$ The activity of glutathione peroxidase, a selenoenzyme, was also lower in the cigarette smokers. This enzyme is responsible for the removal of hydrogen peroxide and other organic hydroperoxides formed during cellular oxidative metabolism. Glutathione peroxidase has a close metabolic relation with vitamin $E$, another important antioxidant. This fat soluble vitamin, present in cellular and subcellular membranes, provides a defence against peroxidation of vital phospholipids. The biochemical actions of vitamin $\mathrm{E}$ and glutathione peroxidase are therefore concerned with the prevention of peroxidative damage to cells and subcellular elements. ${ }^{21}$

The main aim of this study was to examine the concentrations of selenium and vitamin $E$ in blood samples from a group of healthy men, between 30 and 50 years of age, in relation to other accepted risk factors for coronary heart disease.

\section{Subjects and methods}

\section{SUBJECTS}

A total of 123 apparently healthy men between 30 and 50 years of age participated in the study. Of these volunteers, 94 were hospital employees and the remaining 29 were employed by a local firm. The subjects were asked to complete a questionnaire ${ }^{8}$ which included details of their occupation, height, and weight, as vell as alcohol consumption and smoking habits. In addition, the subjects were asked about recent medication and major illnesses; full details are given in Table 1. Blood samples were obtained by venepuncture between 8.00 am and 10.00 am after each subject had abstained from food and drink, other than water, for at least $12 \mathrm{~h}$. Blood pressure was measured with each subject in the sitting position by the same observer using a Reister sphygmomanometer.

\section{METHODS}

Haematological parameters were measured within 4 h of blood sampling using a Coulter counter and Hawksley microhaematocrit centrifuge. Samples for glutathione peroxidase, vitamin $\mathrm{E}$, and plasma glucose measurement were stored at $4^{\circ} \mathrm{C}$ and assayed within $48 \mathrm{~h}$. Serum and whole blood samples were stored at $-20^{\circ} \mathrm{C}$ before analysis for lipids, albumin, and trace elements. Table 2 gives details of the methods, including instrumentation, for the biochemical analysis of the blood samples together with the between batch precision of analysis. An obesity index ${ }^{32}$ for each subject was calculated from the formula:

$$
\frac{\text { weight in kilograms }}{\text { (height in metres) }^{2}}
$$

\section{STATISTICAL ANALYSIS}

Data processing was carried out on an ICL 2970 computer and the appropriate statistics were obtained using the SPSS package. ${ }^{33}$

\section{Results}

Seven of the original 123 male volunteers who took part in the study were excluded. Current drug treatment or past medical history accounted for five of the subjects who were excluded. The other two subjects excluded were a man who had a fasting plasma glucose concentration of $8.9 \mathrm{mmol} / 1$ and a

Table 1 Details of subjects

\begin{tabular}{|c|c|c|c|c|c|}
\hline & \multicolumn{2}{|c|}{ Age group $30-40$ years } & \multicolumn{2}{|c|}{ Age group 41-50 years } & \multirow[t]{2}{*}{ Tota } \\
\hline & No & (\% of total) & No & (\% of total) & \\
\hline All subjects & 73 & $(62 \cdot 9)$ & 43 & $(37 \cdot 1)$ & 116 \\
\hline $\begin{array}{l}\text { Occupational groups } \\
\text { Manual workers } \\
\text { Non-manual workers }\end{array}$ & $\begin{array}{l}17 \\
56\end{array}$ & $\begin{array}{l}(68 \cdot 0) \\
(61 \cdot 5)\end{array}$ & $\begin{array}{r}8 \\
35\end{array}$ & $\left(\begin{array}{l}32 \cdot 0) \\
38 \cdot 5\end{array}\right)$ & $\begin{array}{l}25 \\
91\end{array}$ \\
\hline $\begin{array}{l}\text { Tobacco consumption } \\
\text { Non-smokers } \\
\text { Cigarette smokers } \\
\text { Pipe and cigar smokers }\end{array}$ & $\begin{array}{r}41 \\
29 \\
3\end{array}$ & $\left.\begin{array}{l}(62 \cdot 1) \\
70 \cdot 7 \\
33 \cdot 3\end{array}\right)$ & $\begin{array}{r}25 \\
12 \\
6\end{array}$ & $\begin{array}{l}(37 \cdot 9) \\
29 \cdot 3) \\
(66 \cdot 7)\end{array}$ & $\begin{array}{r}66 \\
41 \\
9\end{array}$ \\
\hline $\begin{array}{l}\text { Alcohol consumption } \\
\text { Non-drinkers* } \\
\text { Weekend drinkers } \\
\text { Daily drinkers }\end{array}$ & $\begin{array}{l}15 \\
28 \\
30\end{array}$ & $\begin{array}{l}(65 \cdot 2) \\
68 \cdot 3 \\
57 \cdot 7)\end{array}$ & $\begin{array}{r}8 \\
13 \\
22\end{array}$ & $\begin{array}{l}(34 \cdot 8) \\
31 \cdot 7 \\
(42 \cdot 3)\end{array}$ & $\begin{array}{l}23 \\
41 \\
52\end{array}$ \\
\hline
\end{tabular}

*This group also includes those subjects who drank alcohol only very occasionally 
Table 2 Details of sample analysis

\begin{tabular}{|c|c|c|c|}
\hline Analysis & Methodology & $\begin{array}{l}\text { Between batch } \\
\text { precision (\%) }\end{array}$ & Instrumentation \\
\hline Albumin & Immunoturbidimetry ${ }^{22}$ & $3 \cdot 1$ & LKB 8600 reaction rate analyser \\
\hline Glucose & Glucose oxidase ${ }^{23}$ & $1 \cdot 1$ & Technicon autoanalyser \\
\hline Total cholesterol & $\begin{array}{l}\text { Enzymatic assay using BCL } \\
\text { kit no: } 290319^{24}\end{array}$ & $3 \cdot 9$ & $\begin{array}{l}\text { Instrumentation laboratory micro- } \\
\text { centrifugal analyser Multistat III }\end{array}$ \\
\hline HDL cholesterol & $\begin{array}{l}\text { Precipitation of LDL and very LDL } \\
\text { followed by cholesterol assay } \\
\text { of the supernatant }{ }^{25}\end{array}$ & $5 \cdot 2$ & $\begin{array}{l}\text { Instrumentation laboratory microcen- } \\
\text { trifugal analyser Multistat III }\end{array}$ \\
\hline Triglycerides & $\begin{array}{l}\text { Enzymatic assay using BCL } \\
\text { kit no: } 126012^{26}\end{array}$ & $3 \cdot 4$ & LKB 8600 reaction rate analyser \\
\hline Glutathione peroxidase & $\begin{array}{l}\text { Coupled reaction system using } \\
\text { t-butyl hydroperoxide }\end{array}$ & $7 \cdot 6$ & LKB 8600 reaction rate analyser \\
\hline Selenium & $\begin{array}{l}\text { Hydride generation and atomic } \\
\text { absorption spectrophotometry }{ }^{28}\end{array}$ & $4 \cdot 9$ & $\begin{array}{l}\text { Perkin Elmer Model } 360 \text { atomic } \\
\text { absorption spectrophotometer }\end{array}$ \\
\hline Vitamin E & High pressure liquid chromatography ${ }^{24}$ & $3 \cdot 4$ & $\begin{array}{l}\text { Laboratory Data Control pump } \\
\text { and UV detector }\end{array}$ \\
\hline Cadmium & $\begin{array}{l}\text { Electrothermal atomisation and atomic } \\
\text { absorption spectrophotometry }\end{array}$ & $5 \cdot 8$ & $\begin{array}{l}\text { Perkin Elmer Model } 2380 \text { atomic } \\
\text { absorption spectrophotometer }\end{array}$ \\
\hline Lead & Atomic absorption spectrophotometry ${ }^{31}$ & $3 \cdot 2$ & $\begin{array}{l}\text { Perkin Elmer Model } 360 \text { atomic } \\
\text { absorption spectrophotometer }\end{array}$ \\
\hline
\end{tabular}

HDL = high density lipoprotein; $\mathbf{L D L}=$ low density lipoprotein

family history of diabetes and another man whose plasma sample was grossly lipaemic, with a triglyceride value of $8.8 \mathrm{mmol} / \mathrm{l}$ and a raised plasma glucose concentration. Some of the remaining 116 subjects had blood lipid concentrations outside the accepted reference ranges: 18 men had fasting triglyceride concentrations greater than $2.2 \mathrm{mmol} / \mathrm{l}$, and five had triglyceride concentrations greater than $3.0 \mathrm{mmol} / \mathrm{l}$. In this group three men had total cholesterol concentrations greater than $8.0 \mathrm{mmol} / \mathrm{l}$. A further group of five men also had total cholesterol concentrations greater than $8.0 \mathrm{mmol} / \mathrm{l}$. As this proportion of abnormal lipid results was similar to the findings of other workers also studying an apparently healthy population, ${ }^{3435}$ all the subjects were included in the study. None of the subjects was hypertensive.

To test the homogeneity of the sample population the subjects were divided into groups according to age, then occupation, and finally place of employ- ment. The results for the various groups were compared by parametric ( $t$ test) and non-parametric (Mann-Whitney) analysis. Table 1 shows that there was a higher proportion of subjects in the $30-40$ age group $(63 \%)$ compared with the $41-50$ age group $(37 \%)$. No significant differences were found for any of the parameters except for plasma glucose, which was higher in the older age group (mean 5.07 $\mathrm{mmol} / \mathrm{l}$, SD 0.494) compared with the younger group (mean $4.86 \mathrm{mmol} / \mathrm{l}, \mathrm{SD} 0.423$ ), $\mathrm{p}<0.05$, and serum albumin, which was lower in the older age group (mean $43.8 \mathrm{~g} / \mathrm{l}, \mathrm{SD} 3.92$ ) compared with t: : younger group (mean $45 \cdot 5 \mathrm{~g} / \mathrm{l}, \mathrm{SD} 3 \cdot 14$ ), $\mathrm{p}<0.02$. There were fewer manual workers $(21.5 \%)$ than non-manual workers $(78.5 \%)$, and a higher proportion of the manual workers admitted to smoking than the non-manual workers. No significant differences were found in the parameters for the two groups. Similarly, significant differences were not found between the parameters for the subjects from

Table 3 Comparison of results according to smoking groups

\begin{tabular}{|c|c|c|c|c|}
\hline \multirow[t]{2}{*}{ Analysis } & \multicolumn{2}{|c|}{$\begin{array}{l}\text { Non-smokers } \\
(\mathrm{n}=66)\end{array}$} & \multicolumn{2}{|c|}{$\begin{array}{l}\text { Cigarette smokers } \\
(\mathrm{n}=41)\end{array}$} \\
\hline & Mean & (SD) & Mean & (SD) \\
\hline $\begin{array}{l}\text { Haemoglobin }(\mathrm{g} / \mathrm{dl}) \\
\text { Plasma glucose }(\mathrm{mmol} / \mathrm{l}) \\
\text { Serum albumin }(\mathrm{g} / \mathrm{l}) \\
\text { Total cholesterol }(\mathrm{mmol} / \mathrm{l}) \\
\text { HDL cholesterol }(\mathrm{mmol} / \mathrm{l}) \\
\text { Triglycerides }(\mathrm{mmol} / \mathrm{l}) \\
\text { Obesity index } \\
\text { Diastolic blood pressure }(\mathrm{mmHg}) \\
\text { Systolic blood pressure }(\mathrm{mmHg})\end{array}$ & $\begin{array}{c}15 \cdot 3 \\
4 \cdot 9 \\
44 \cdot 7 \\
5 \cdot 7 \\
1 \cdot 25 \\
1 \cdot 32 \\
23 \cdot 5 \\
76 \cdot 2 \\
119 \cdot 7\end{array}$ & $\begin{array}{l}(0.91) \\
(0 \cdot 45) \\
(3 \cdot 33) \\
(1 \cdot 17) \\
(0.273) \\
(0.659) \\
(2 \cdot 20) \\
(10.8) \\
(14 \cdot 3)\end{array}$ & $\begin{array}{c}15 \cdot 9^{*} \\
4 \cdot 9 \\
45 \cdot 0 \\
5 \cdot 8 \\
1 \cdot 20 \\
1 \cdot 84 \dagger \\
24 \cdot 5 \\
77 \cdot 1 \\
120 \cdot 9\end{array}$ & $\begin{array}{l}(1 \cdot 03) \\
(0.44) \\
(3.40) \\
(1 \cdot 12) \\
(0.318) \\
(0.795) \\
(2.96) \\
(9 \cdot 2) \\
(13.6)\end{array}$ \\
\hline
\end{tabular}

HDL $=$ high density lipoprotein. ${ }^{*} p<0.005,+p<0.001$. 
Table 4 Vitamin E and trace elements according to smoking groups

\begin{tabular}{|c|c|c|c|c|c|c|}
\hline \multirow[t]{2}{*}{ Analysis } & \multicolumn{2}{|c|}{$\begin{array}{l}\text { Non-smokers } \\
(\mathrm{n}=66)\end{array}$} & \multicolumn{2}{|c|}{$\begin{array}{l}\text { Cigarette smokers } \\
(\mathrm{n}=41)\end{array}$} & \multicolumn{2}{|c|}{$\begin{array}{l}\text { Pipe and cigar smokers } \\
(\mathrm{n}=9)\end{array}$} \\
\hline & Mean & $(S D)$ & Mean & $(S D)$ & Mean & $(S D)$ \\
\hline $\begin{array}{l}\text { Vitamin E ( } \mu \mathrm{mol} / \mathrm{l}) \\
\text { Glutathione peroxidase }(\mathrm{U} / \mathrm{g} \text { Hb) } \\
\text { Whole blood selenium }(\mu \mathrm{g} / 1) \\
\text { Serum selenium }(\mu \mathrm{g} / \mathrm{l}) \\
\text { Whole blood cadmium }(\mu \mathrm{g} / \mathrm{l}) \\
\text { Selenium:cadmium }(\mu \mathrm{mol} / \mathrm{l}) \\
\text { Selenium:lead }(\mu \mathrm{mol} / \mathrm{l})\end{array}$ & $\begin{array}{c}25 \cdot 4 \\
17 \cdot 9 \\
134 \cdot 3 \\
114 \cdot 5 \\
0 \cdot 95 \\
249 \\
3 \cdot 3\end{array}$ & $\begin{array}{c}(6 \cdot 77) \\
(3 \cdot 45) \\
(20.43) \\
(15 \cdot 71) \\
(0.422) \\
(159) \\
(1 \cdot 00)\end{array}$ & $\begin{array}{c}24 \cdot 4 \\
16 \cdot 5^{*} \\
115 \cdot 1 \dagger \\
98 \cdot 4 \dagger \\
2 \cdot 11 \dagger \\
111 \dagger \\
2 \cdot 6^{*}\end{array}$ & $\begin{array}{l}(6 \cdot 04) \\
(3.61) \\
(10.84) \\
(11.01) \\
(1 \cdot 287) \\
(83) \\
(0.98)\end{array}$ & $\begin{array}{c}23 \cdot 7 \\
18 \cdot 4 \\
121 \cdot 9 \\
105 \cdot 9 \\
0 \cdot 44 \\
265 \\
2 \cdot 9\end{array}$ & $\begin{array}{c}(4 \cdot 60) \\
(4 \cdot 36) \\
(21 \cdot 29) \\
(13 \cdot 30) \\
(0 \cdot 442) \\
(252) \\
(0 \cdot 99)\end{array}$ \\
\hline
\end{tabular}

${ }^{*}$ Cigarette smokers $v$ non-smokers, $\mathrm{p}<0.05$.

tCigarette smokers $v$ non-smokers, $\mathrm{p}<0.001$.

either place of employment. Consequently all 116 subjects were treated as one group, regardless of age or occupation.

The smoking habits and alcohol consumption for each subject had been recorded in detail, but as only nine men admitted to smoking more than 20 cigarettes a day all the cigarette smokers were combined into one group. Alcohol consumption was divided into three categories; occasional and non-drinkers, weekend drinkers, and daily drinkers. Only four men who drank alcohol daily admitted to consuming three or more pints of beer, or its equivalent, each day.

The haemoglobin, albumin, glucose, and lipid concentrations for the cigarette smokers and nonsmokers are shown in Table 3, together with the results for the obesity index and the blood pressure measurements for each group. Haemoglobin and triglyceride concentrations were significantly higher in the cigarette smokers compared with the nonsmokers but were not significantly different for the pipe and cigar smokers when compared with either

Table 5 Effects of cigarette smoking without alcohol consumption

\begin{tabular}{|c|c|c|c|c|}
\hline \multirow[t]{3}{*}{ Analysis } & \multicolumn{4}{|c|}{ Non-drinkers } \\
\hline & \multicolumn{2}{|c|}{$\begin{array}{l}\text { Non-smokers } \\
(\mathrm{n}=15)\end{array}$} & \multicolumn{2}{|c|}{$\begin{array}{l}\text { Cigarette smokers } \\
(\mathrm{n}=7)\end{array}$} \\
\hline & Mean & $(S D)$ & Mean & $(S D)$ \\
\hline $\begin{array}{l}\text { Serum triglyceride }(\mathrm{mmol} / \mathrm{l}) \\
\text { Glutathione peroxidase }(\mathrm{U} / \mathrm{g} \mathrm{Hb}) \\
\text { Whole blood selenium }(\mu \mathrm{g} / \mathrm{l}) \\
\text { Serum selenium }(\mu \mathrm{g} / \mathrm{l}) \\
\text { Whole blood cadmium }(\mu \mathrm{g} / \mathrm{l}) \\
\text { Whole blood lead }(\mu \mathrm{g} / \mathrm{dl})\end{array}$ & $\begin{array}{c}1 \cdot 18 \\
19 \cdot 1 \\
132 \cdot 8 \\
112 \cdot 4 \\
1 \cdot 06 \\
11 \cdot 7\end{array}$ & $\begin{array}{c}(0.568) \\
(3.85) \\
(17.30) \\
(11.64) \\
(0.643) \\
(3.64)\end{array}$ & $\begin{array}{c}1 \cdot 63 \\
15 \cdot 7^{*} \\
114 \cdot 7 \dagger \\
102 \cdot 0 \\
1 \cdot 84 \\
10 \cdot 2\end{array}$ & $\begin{array}{l}(0.401) \\
(2 \cdot 22) \\
(8 \cdot 60) \\
(10.41) \\
(0.643) \\
(3.08)\end{array}$ \\
\hline
\end{tabular}

${ }^{*} \mathrm{p}<0.05,+\mathrm{p}<0.02$.

Table 6 Effects of cigarette smoking with daily alcohol consumption

\begin{tabular}{|c|c|c|c|c|}
\hline \multirow[t]{3}{*}{ Analysis } & \multicolumn{4}{|c|}{ Daily drinkers } \\
\hline & \multicolumn{2}{|c|}{$\begin{array}{l}\text { Non-smokers } \\
(\mathrm{n}=29)\end{array}$} & \multicolumn{2}{|c|}{$\begin{array}{l}\text { Cigarette smokers } \\
(\mathrm{n}=18)\end{array}$} \\
\hline & Mean & $(S D)$ & Mean & $(S D)$ \\
\hline $\begin{array}{l}\text { Serum triglyceride }(\mathrm{mmol} / \mathrm{l}) \\
\text { Glutathione peroxidase }(\mathrm{U} / \mathrm{g} \mathrm{Hb}) \\
\text { Whole blood selenium }(\mu \mathrm{g} / \mathrm{l}) \\
\text { Serum selenium }(\mu \mathrm{g} / \mathrm{l}) \\
\text { Whole blood cadmium }(\mu \mathrm{g} / \mathrm{l}) \\
\text { Whole blood lead }(\mu \mathrm{g} / \mathrm{dl})\end{array}$ & $\begin{array}{c}1 \cdot 24 \\
17 \cdot 9 \\
137 \cdot 7 \\
114 \cdot 2 \\
0 \cdot 89 \\
12 \cdot 1\end{array}$ & $\begin{array}{c}(0 \cdot 473) \\
(3 \cdot 65) \\
(23 \cdot 30) \\
(18 \cdot 58) \\
(0.341) \\
(2 \cdot 72)\end{array}$ & $\begin{array}{l}1 \cdot 81^{*} \\
17 \cdot 3 \\
113 \cdot 5 \dagger \\
95 \cdot 1 \dagger \\
2 \cdot 16 \dagger \\
14 \cdot 5\end{array}$ & $\begin{array}{c}(1 \cdot 011) \\
(3 \cdot 88) \\
(12 \cdot 49) \\
10.02) \\
(1 \cdot 120) \\
(4 \cdot 56)\end{array}$ \\
\hline
\end{tabular}

${ }^{*} p<0.05$, tp $<0.001$. 
the non-smokers or the cigarette smokers.

The effect of cigarette smoking on glutathione peroxidase activity and concentrations of selenium, cadmium and lead is shown in Table 4. The plasma and whole blood selenium concentrations were significantly lower in the cigarette smokers compared with the non-smokers, whereas the concentrations of lead and cadmium were significantly higher in the cigarette smokers. These differences had an appreciable effect on the selenium:cadmium and selenium:lead ratios. The concentrations of each element in the cigar and pipe smoking group fell between those of the non-smokers and cigarette smokers, but these differences were not statistically significant. There appeared to be no difference in the vitamin $E$ concentrations for any of the smoking groups.

Tables 5 and 6 show the effect of classifying the non-smokers and cigarette smokers according to their alcohol consumption. Glutathione peroxidase activity and serum and blood selenium concentrations were lower in the cigarette smokers compared with the non-smokers, but no significant differences were found between the non-drinking cigarette smokers and the smokers who drank alcohol daily. Similarly, no significant differences were found between the non-drinkers and the daily drinkers in the non-smoking group. The concentrations of cadmium and serum triglyceride were higher in the cigarette smoking groups, whereas daily alcohol consumption seemed to have a greater effect on the concentration of lead in blood. The independent effects of cigarette smoking and alcohol consumption on the results were confirmed by analysis of variance. No significant differences were found for blood pressure, obesity index, total cholesterol, albumin, glucose, or vitamin $\mathrm{E}$.

The possibility existed that cadmium and lead might have had an effect on blood selenium concentration. Analysis of covariance, however, showed that neither cadmium nor lead had a significant effect on blood selenium concentrations.

The data were examined for possible associations between selenium concentration, vitamin $E$, and the cardiovascular risk factors. Glutathione peroxidase was not associated with any of the risk factors (apart from smoking); however, both whole blood and serum selenium concentrations showed a weak negative association with blood cadmium concentrations $(r=-0 \cdot 24, p=0 \cdot 01)$. Vitamin $E$ showed a strong association with total cholesterol $(r=0.67$, $p<0.001$ ) and to a lesser extent with serum triglyceride $(r=0.44, p<0.001)$. There was also a weak correlation between vitamin $E$ and plasma selenium concentration $(r=0.32, p<$ 0.001).

\section{Discussion}

All the men included in the study presented as apparently healthy subjects without a history of diabetes, hypertension, or heart disease. Blood lipid concentrations above the accepted reference ranges were found in 23 subjects. Several other workers have reported similar abnormal lipids in an apparently healthy population, ${ }^{3435}$ and we therefore included all 116 subjects as they seemed to be representative of a "normal" population.

The age group for the study was limited to $30-50$ years to minimise changes in the parameters which might be due to age alone. Only plasma glucose, which was higher in the older age group, and serum albumin, which was lower, showed significant differences between the two groups. The mean concentrations of both serum triglyceride and total cholesterol were higher in the older age group, but the differences were not significant.

The metabolic changes due to smoking and alcohol consumption have been reviewed elsewhere. ${ }^{36}$ Previous workers have reported an association between alcohol consumption and high density lipoprotein cholesterol, ${ }^{37}$ a finding confirmed in this study. The mean concentration of high density lipoprotein cholesterol was $1.12 \mathrm{mmol} / \mathrm{l}$ for the non-drinkers (SD 0.276, $\mathrm{n}=23$ ) compared with $1.33 \mathrm{mmol} / \mathrm{l}$ for the daily drinkers (SD $0.326, \mathrm{n}=$ 52), $\mathrm{p}<0 \cdot 01$.

Although only nine men admitted to smoking more than 20 cigarettes a day, we found the expected increase in haemoglobin and triglyceride concentrations in the smoking group. ${ }^{37}$ Significant increases in the concentrations of cadmium and lead were also found in the smokers, as well as a decrease in selenium concentration. Multivariate analysis of the data showed that the decrease in selenium and the increase in cadmium in the cigarette smokers was independent of alcohol consumption. The results for the pipe and cigar smoking group were intermediate between those of the cigarette smokers and the non-smokers. These results may lack statistical significance because only nine men smoked pipes or cigars. Alternatively, the fact that cigar and pipe smokers do not usually inhale smoke may have a considerable influence on the results.

The reason for the lower concentrations of selenium in the cigarette smokers is not yet understood. Selenium undergoes a complex chemical transformation in the red cells which is dependent on an adequate supply of glutathione. Competition of cadmium with selenium for the SH sites or the formation of a cadmium/selenium complex may interfere with the metabolism of selenium. Early studies showed that selenium is initially transported 
by serum albumin and then bound to $\alpha_{1-}$ and $\alpha_{2-}$ globulins, and studies have also shown an association of selenium with plasma lipoproteins. ${ }^{38} \mathrm{We}$ did not find reduced serum albumin concentrations in the smoking group, but confirmed an increase in triglyceride concentrations. The lower concentrations of selenium found in the cigarette smokers did not therefore relate to lower albumin or lipid concentrations. Motsenbocker and Tappe ${ }^{39}$ have identified a selenium binding protein in rat plasma and plasma from a Rhesus monkey, which has a molecular weight of 80000 with a selenopolypeptide size of 45000 . Experimental evidence showed that the selenium was present in the form of selenocysteine. They suggest that this selenium binding plasma protein is engaged in selenium transport and that it delivers selenium in the form of selenocysteine to various body tissues. If this protein also exists in human blood then increased concentrations of cadmium in blood may affect the binding of selenium to this protein and hence the transport of selenium to the tissues. York et $a^{40}$ described the effect of in vivo cigarette smoke exposure on glutathione peroxidase related enzyme systems in rat lung. After 21 days' exposure the activity of glutathione peroxidase was increased by $34 \%$, although detectable histological lesions were not found. They suggested that short term, low level exposure to cigarette smoke is capable of initiating metabolic changes in lung cells. ${ }^{40}$ Such changes in alveolar cells may lead to an increased excretion of selenium via the breath, particularly after long term chronic inhalation.

Neither alcohol consumption nor smoking had any effect on the vitamin $E$ concentrations in this study. Because vitamin $E$ is not synthesised in the body the concentration found in plasma is partly dependent on the amount of biologically active vitamin $\mathrm{E}$ being consumed. Behrens et $\mathrm{al}^{41}$ showed that low density and high density lipoproteins were the main carriers of vitamin $E$ in plasma. It is therefore not surprising that we found a strong association between serum lipid and vitamin $\mathrm{E}$ concentrations. The significant increase in the triglyceride concentrations of the smokers, however, was not matched by a comparable increase in vitamin $E$. The weak association of vitamin $E$ with plasma selenium may also be a reflection of dietary intake.

The results for all the factors measured in this study were consistent with the expected results from an apparently healthy group of men aged 30-50 years. We were unable to show an association between selenium concentration and the risk factors for cardiovascular disease with the exception of cigarette smoking, but a similar association was not seen with vitamin E. None of the subjects studied were selenium deficient; nevertheless, the blood selenium concentrations in the cigarette smokers were significantly lower than in the non-smokers. If, as many reports now suggest, selenium and vitamin $\mathrm{E}$ are protective elements against coronary heart disease, then an explanation of the effect of smoking on selenium concentration 'would be useful in understanding the aetiology of coronary heart disease.

We thank the Wessex Regional Health Authority for their financial support of this study. We also thank all the men who volunteered to take part in the study and, in particular, the staff and management of Chloride Standby Systems Ltd, Southampton. Finally, we thank Miss L Hinks for carrying out the blood lead measurements and Miss L Snow for typing the manuscript.

\section{References}

' Kannel WB, Castelli WP, Gordon T, McNamara PM. Serum cholesterol lipoproteins and the risk of coronary heart disease. The Framingham Study. Ann Intern Med 1971;74:1-12.

${ }^{2}$ Reid DD, Hamilton PJS, McCartney P, Rose G, Jarrett RJ, Keen $\mathrm{H}$. Smoking and other risk factors for coronary heart disease in British Civil Servants. Lancet 1976;ii:979-84.

${ }^{3}$ Salonen JT, Puska P, Kottke TE. Smoking, blood pressure and serum cholesterol as risk factors of acute myocardial infarction and death among men in Eastern Finland. Eur Heart $J$ 1981;2:365-73.

4 Oliver MF. Does control of risk factors prevent coronary heart disease? Br Med J 1982;285:1065-6.

${ }^{5}$ Mulcahy $R$. Influence of cigarette smoking on morbidity and mortality after myocardial infarction. $\mathrm{Br}$ Heart $J$ 1983;49:410-5.

- World Health Organisation. Environmental health criteria 3. Lead. Geneva: WHO, 1977: 120-1.

7 Carroll RE. The relationship of cadmium in the air to cardiovascular disease death rates. JAMA 1966;198:267-9.

${ }^{8}$ Shaper AG, Pocock SJ, Walker $M$ et al. Effects of alcohol and smoking on.blood lead in middle-aged British men. $\mathrm{Br}$ Med J 1982; 284:299-302.

${ }^{9}$ Ellis KJ, Vartsky D, Zanzi I, Cohn SH, Yasumura S. Cadmium: In vivo measurement in smokers and non-smokers. Science 1979;205:323-5.

${ }^{10}$ Dally S, Maury PH, Boidard D, Bacle S, Gaultier M. Blood cadmium level and hypertension in humans. Clin Toxicol 1978;13:403-8.

"Ward RJ, Fisher M, Tellez-Yudilevich M. Significance of blood cadmium concentrations in patients with renal disorders or essential hypertension and the normal population. Ann Clin Biochem 1978;15:197-200.

12 Perry HM, Erlanger MW, Perry EP. Prevention of cadmiuminduced hypertension by selenium, zinc and hard water. In: Hemphill DD, ed. Trace substances in environmental health, VIII. Columbia: University of Missouri, $1975 ; 339-48$.

${ }^{13}$ Godwin KO. Abnormal electrocardiograms in rats fed a low selenium diet. $Q J$ Exp Physiol 1965;50:282-8.

${ }_{14}$ Godwin KO, Fraser JF. Abnormal electrocardiograms, blood pressure changes and some aspects of the histopathology of selenium deficiency in lambs. $Q J$ Exp Physiol 1966;51:94102.

15 Van Vleet JF, Ferrans VJ, Ruth GR. Ultrastructural alterations in nutritional cardiomyopathy of selenium-vitamin $\mathrm{E}$ deficient 
swine. Lab Invest 1977;37:188-211.

${ }^{16}$ Shamberger RJ, Willis CE, McCormack LJ. Selenium and heart disease. III-Blood selenium and heart mortality in 19 states. In: Hemphill DD ed. Trace substances in environmental health XIII. Columbia: University of Missouri, 1979; 59-62.

${ }^{17}$ Keshan Disease Research Group of the Chinese Academy of Medical Sciences. Keshan disease and selenium in China. Curr Conc Nutr 1982;11:127-38.

${ }^{18}$ Salonen JT, Alfthan G, Huttunen JK, Pikkarainen J, Puska P. Association between cardiovascular death and myocardial infarction and serum selenium in a matched pair longitudinal study. Lancet 1982;ii:175-8.

${ }^{19}$ Oster O, Prellwitz W, Kasper W, Meinertz T. Congestive cardiomyopathy and the selenium content of serum. Clin Chim Acta 1983;128:125-32.

${ }^{20}$ Lloyd B, Lloyd RS, Clayton BE. The effect of smoking, alcohol and other factors on the selenium status of a healthy population. J Epidemiol Community Health 1983;37:213-7.

${ }^{21}$ Scott ML. Advances in our understanding of vitamin E. Fed Proc 1980;39:2736-9.

${ }^{22}$ Spencer K, Price CP. Kinetic immunoturbidimetry: The estimation of albumin. Clin Chim Acta 1979;95:263-76.

${ }^{23}$ Gutteridge JMC. A simple automated guaiacum glucose-oxidase method. J Med Lab Tech 1968;25:385-6.

${ }^{24}$ Roschlau P, Bernt E, Gruber W. Enzymatische bestimmung des gesamt-cholesterins im serum. Z Klin Chem Klin Biochem 1974;12:403-7.

${ }^{25}$ Lopes-Virella MF, Stone P, Ellis S, Collwell JA. Cholesterol determination in high density lipoproteins separated by 3 different methods. Clin Chem 1977;23:882-4.

${ }^{26}$ Wahlefeld AW. Triglycerides: determination after enzymatic hydrolysis. In: Bergmeyer HU ed. Methods of enzymatic analysis, vol 4. 2nd ed. New York: Academic Press, 1974; 1831-5.

${ }^{27}$ Beutler E. A manual of biochemical methods. 2nd ed. New York: Grune and Stratton, 1979: 71-3.

${ }^{28}$ Lloyd B, Holt P, Delves HT. Determination of selenium in biological samples by hydride generation and atomic absorption spectroscopy. Analyst 1982;107:927-33.

${ }^{29}$ Bieri G, Tolliver TJ, Catignani GL. Simultaneous determination of alpha-tocopherol and retinol in plasma or red cells by high pressure liquid chromatography. Am $J$ Clin Nutr 1979;32:2143-9.
${ }^{30}$ Delves HT, Woodward J. Determination of low levels of cadmium in blood by electrothermal atomization and atomic absorption spectrophotometry. Atom Spectrosc 1981;2:65-7.

${ }^{31}$ Delves HT. A microsampling method for the rapid determination of lead in blood by atomic absorption spectrophotometry. Analyst 1970;95:431-8.

${ }^{32}$ Khosla T, Lowe CR. Indices of obesity derived from body weight and height. Br J Prev Soc Med 1967;21:122-8.

${ }^{33} \mathrm{Nie} \mathrm{NH}$, Hull CH, Jenkins JG, Steinbrenner K, Bent DM. Statistical package for the social sciences. 2nd ed. New York: McGraw-Hill, 1975.

${ }^{34}$ Lewis B, Chait A, Wooton IDP, et al. Frequency of risk factors for ischaemic heart disease in a healthy British population, with particular reference to serum-lipoprotein levels. Lancet 1974;i:141-6.

${ }^{35}$ Fuller JH, Pinney S, Jarrett RJ, Kilbourn K, Keen H. Plasma lipids in a London population and their relation to other risk factors for coronary heart disease. Br Heart $J$ 1978;40:170-6.

${ }^{36}$ Young DS. Biological variability. In: Brown S, Mitchell FL, Young DS, eds. Chemical diagnosis of disease. Amsterdam: Elsevier/North Holland Biomedical Press, 1979: 55-86.

${ }^{37}$ Bainton D, Burns-Cox CJ, Elwood PC et al. Prevalence of ischaemic heart disease and associations with serum lipoproteins in subjects aged 45 to 64 years. The Speedwell Study. Br Heart J 1982;47:483-9.

${ }^{38}$ Underwood EJ. Trace elements in human and animal nutrition. 4th ed. New York: Academic Press, 1977: 302-46.

${ }^{39}$ Motsenbocker MA, Tappel AL. Selenocysteine-containing proteins from rat and monkey plasma. Biochim Biophys Acta 1982; 704:253-60.

${ }^{40}$ York GK, Peirce TH, Schwartz LW, Cross CE. Stimulation by cigarette smoke of glutathione peroxidase system enzyme activities in rat lung. Arch Environ Health 1976;31:286-90.

${ }^{41}$ Behrens WA, Thompson JN, Madere R. Distribution of alphatocopherol in human plasma lipoproteins. Am J Clin Nutr 1982;35:691-6.

Requests for reprints to: Barbara Lloyd, Room LD62, South Laboratory and Pathology Block, Southampton General Hospital, Tremona Road, Southampton, SO9 4XY, Enland. 